\title{
CDK2AP2 Gene
}

National Cancer Institute

\section{Source}

National Cancer Institute. CDK2AP2 Gene. NCI Thesaurus. Code C24347.

This gene plays a regulatory role in cell cycle events. 